\title{
Travaux Preparatoires and United Nations Treaties or Conventions: Using the Web Wisely
}

Marylin J. Raisch

Georgetown University Law Center, mjr47@law.georgetown.edu

This paper can be downloaded free of charge from:

https://scholarship.law.georgetown.edu/facpub/184

30 Int'l J. Legal Info 324-330 (2002)

This open-access article is brought to you by the Georgetown Law Library. Posted with permission of the author. Follow this and additional works at: https://scholarship.law.georgetown.edu/facpub

Part of the Legal Writing and Research Commons 


\title{
GEORGETOWN LAW Faculty Publications
}

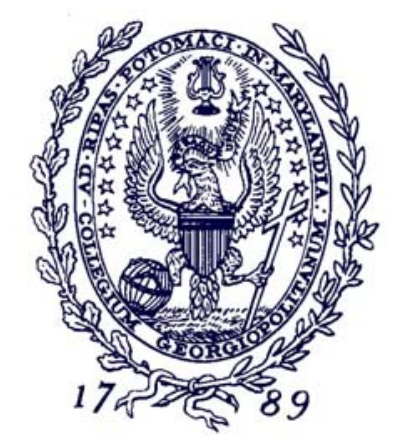

February 2010

\section{Travaux Preparatoires and United Nations Treaties or Conventions: Using the Web Wisely}

30 Int'l J. Legal Info 324-330 (2002)

\author{
Marylin Raisch \\ Associate Law Librarian for International and Foreign Law \\ Georgetown University Law Center \\ mjr47@law.georgetown.edu
}

This paper can be downloaded without charge from:

Scholarly Commons: http://scholarship.law.georgetown.edu/facpub/184/

Posted with permission of the author 


\section{Travaux Préparatoires and United Nations Treaties or Conventions: Using the Web Wisely}

\section{Research Tips and Observations}

\section{MARYLIN RAISCH*}

One of the spectacular and liberating features of the Internet in general and the United Nations web site in particular is that if a treaty you are researching was drafted in connection with a conference relating to human rights, the environment, development, or a major topic in criminal or commercial law, entire web pages based on the treaty and its history are now in place. The process of drafting and finalizing the texts of major conventions and treaties sponsored by bodies within the United Nations system is unusually well-documented. The conference process and other drafting procedures have always made researching UN treaties rather more systematic than is the case with many inter-governmental organizations.

All that said, however, the fact remains that while it is possible to find individual recent documentation relating to the drafting of treaties by searching the Internet via the popular search engines, the results may not always be as comprehensive as the conscientious legal practitioner or scholar might wish. And what of the less well-known multilateral conventions? Alas, it is not only the obscure or bilateral treaties that can be hard to interpret or locate. Travaux for larger conventions may be a challenge as well. An ounce of caution and a larger dose of background knowledge can save the generalist and the specialist

* International and Foreign Law Librarian, Bora Laskin Law Library, University of Toronto, Ontario, Canada. ${ }^{\odot}$ Marylin Raisch 2002. 
librarian, respectively, from the pitfalls of missed documents or gaps that the researcher may all too readily blame on that hapless librarian. ${ }^{1}$

There is no reason to abandon search engines or the web itself if the savvy librarian knows a few tips for online access and is willing to supplement the search with print or other electronic formats. Knowing the drafting process for the UN and some other regional organizations is a starting point for more in-depth knowledge and evaluation of the electronic resources.

\section{WHAT EXACTLY ARE TRAVAUX PRÉPARATOIRES AND WHY WOULD ANYONE WANT TO FIND THEM?}

Literally the "preparatory works," travaux, or documentation of a treaty, may serve as an aid to interpretation of the treaty in the same way as legislative or drafting history might shed light on the wording of a statute. Jonathan Pratter, International and Foreign Law Librarian, Jamail Center for Legal Research, Tarlton Law Library, University of Texas, has created an excellent slide show outline of the research process for travaux, and he includes a list of scholarly definitions on slide 4 of his presentation. ${ }^{2}$ He quotes Jennings and Watts to the effect that travaux are most simply a "record of negotiations preceding the conclusion of a treaty...." ${ }^{33}$ However, such drafting history plays a subsidiary role, according to the Vienna Convention on the Law of Treaties (1965). ${ }^{4}$ Whereas at one time the intention of the parties at the time of drafting played a prominent role, the Vienna Convention requires that it be established

${ }^{1}$ While the researcher can sometimes choose to which librarian a question may be addressed, that is, generalist or specialist, the obverse is not always true: the sitting-duck librarian may not choose the depth or difficulty of any individual question put to him or her.

${ }^{2}$ Jonathan Pratter, "À la recherche des Travaux Préparatoires: A structured Approach to Researching the Drafting History of International Agreements," American Association of Law Libraries (AALL) Workshop, Gateway to Treaty Research in the Digital Age. AALL Annual Meeting, Philadelphia, July 15, 2000, available at http://tarlton.law.utexas.edu/staff/presentations/jpratter/sld001.htm.

3 Oppenheim's International Law [Oppenheim, Lassa (1858-1919], Sir Robert Jennings and Sir Arthur Watts, eds. $9^{\text {th }}$ ed. Harlow, Essex : Longman, 1992 at 1277.

${ }^{4} 1155$ U.N.T.S. 331. 
that there are ambiguities or other special reasons to resort to drafting history. ${ }^{5}$ Why, then, would a researcher be concerned about these documents?

The drafting history of major treaties continues to be of general scholarly interest and a matter of judicial notice despite the cautious note sounded by the Vienna Treaty. To cite some grounds for this generalization, one can point to circumstantial evidence in the form of a Lexis search on the phrase "travaux préparatoires" in the "law reviews combined" file of secondary sources. The phrase appears in 563 law review articles, and a random sample of contextual weight given to the phrase indicated not only that scholars had used these background materials in analysis of treaties but also that courts had made use of them as well. ${ }^{6}$ The March 1999 Pinochet House of Lords decision made frequent reference to the travaux of the Torture and Extradition conventions under consideration in that ground-breaking case on human rights and jurisdiction. ${ }^{7}$

Finally, what exactly are the types of documents to be included? If one looks at some of the many compilations of travaux in print, ${ }^{8}$ one sees the

${ }^{5}$ Art. 31(4), Art. 32. See Bernhardt, R. "Interpretation in International Law, " 7 Encyclopedia of Public International Law at 321-323.

${ }^{6}$ E.g., the Inter-American Court of Human Rights, as summarized in "International Decision: The Right to Information on Consular Assistance in the Framework of the Guarantees of the Due Process of Law." Advisory Opinion OC16/99. A.J.I.L. 94 (2000): 555, 558.

${ }^{7}$ R. v. Bow Street Metropolitan Stipendiary Magistrate and others, ex parte Pinochet Ugarte (Amnesty International and others intervening) (No 3) [2000] 1 AC 147, [1999] 2 All ER 97, [1999] 2 WLR 827. The treaties under discussion were the European Convention on Extradition 1957 (the Extradition Convention), Paris, 13 December 1957; TS 97 (1991); Cmnd 1762; and the Convention against Torture and Other Cruel, Inhuman or Degrading Treatment or Punishment 1984 (the Torture Convention), 10 December 1984; U.N. Res. 39/46, Doc A/39/51, 1465 U.N.T.S. 85 (1987).

${ }^{8}$ See, e.g., Lars Adam REHOF, Guide to the travaux préparatoires of the United Nations Convention on the Elimination of all Forms of Discrimination against Women (Dordrecht; Boston: M. Nijhoff Publishers, 1993); Council of Europe, Collected edition of the "travaux préparatoires" of the European Convention on Human Rights (The Hague; Boston: M. Nijhoff: 1975-1985; Hague Conference on Private International Law, Actes et documents de la ... session: (La Haye: Bureau permanent de la Conférence, 1893-) with volumes from the permanent bureau per se from 1961 on. These are just a few of the more important examples of collected 
documents and proceedings of conferences, working groups, and preparatory committees variously named, reports of special rapporteurs, actual previous drafts with commentary, and the like. Because these documents vary somewhat in type, the appearance of documents on treaty web sites can be misleading. It is important here to distinguish between general background documents, or background information, and travaux. Take, for example, the United Nations Environment Programme Ozone Secretariat, http://www.unep. org/ozone/indexen.shtml, bringing together the related ozone treaties and protocols. Major reports and amending language is posted there, and one can piece together the background. But one is left uncertain as to whether this constitutes the actual travaux or- and this is usually the case with web sites for treaties with monitoring functions- is it more about the present and future of the treaty than its drafting history? This certainly seems to be the case for the Kyoto Protocol at the web site for the United Nations Framework Convention on Climate Change, http://www.unfccc.de/index.html. In short, the major areas where search engines take us easily to the authentic treaty texts fall mainly within the areas of the environment, human rights, and commercial areas such as the United Nations Convention on Contracts for the Sale of Goods. And these sites are concerned more with periodic reporting, jurisprudence, and monitoring, which is indeed the major relevance of the treaties. Enforcement, after all, has given public international law some greater credibility.

THE PROCESS AND THE PLAYERS: PREPARATORY COMMITTEES OR PREP COMS, WORKING GROUPS, THE INTERNATIONAL LAW COMMISSION, THE HUMAN RIGHTS COMMISSION, ETC.

One of the helpful things about the mass of UN documentation is that it is well-organized, even though it is voluminous. Every conference that has ever been held, including those which resulted in a draft treaty, has been assigned a unique number. Once one discovers this number, one can use the fee-based Official Document System database (for treaties negotiated after 1992), www.ods.un.org, in order to call up the documents of that conference. There have been major and minor conferences, and not all of these are listed on the web site, but major ones are listed at the UN-I-QUE (UN Info Quest) service in the documentation page of the UN web site, http://www.un.org/ Depts/dhl/unique/index.html.

travaux. 
To learn the conference numbers and to get a list at least of the final reports of all conferences since 1948, one enters the initial or leading symbol elements for those conferences, either A/CONF or E/CONF. It helps if one knows at the start whether it was a General Assembly body or an Economic and Social Council body which sponsored the conference, but trial and error works as well. One gets a fairly long list by title of conferences by topic, but if you click on the Tin Conference, for example, one finds that it was E/CONF.12 and then one can use ACCESS UN or the microfiche set to get the documents of the 1950 conference (too old for the indexed web, though Google will pick up the 1960 and later meetings at a further point on the travaux time line). This is an ideal way to get information for the un-sexy and not often mentioned conferences that law firms sometimes find relevant to clients' interests in particular goods or services.

If it's hot and new you want, "A/CONF and human rights" in the UN-IQUE search template brings you the World Conference on Human Rights, its dates, location, and handy number, A/CONF.157, and so on. In this way you could get a fairly complete list using paper, fiche and the web.

Another overlooked source is the United Nations Yearbook. ${ }^{9}$ While one must go year by year, it is entirely possible to compile a very complete list of draft documents and reports using each volume's index. It is a CD-ROM product so it has an electronic life as well, although this author is not familiar with that format.

Finally, one should not overlook the role of bodies which have some part to play, either in treaty-drafting directly or in yearly meetings on the codification of international law. These include the International Law Commission and its oft-cited Analytical Guide (with its category-based index), http://www.un.org/law/ilc/guide/gfra.htm, the General Assembly Sixth Committee, http://www.un.org/law/cod/sixth/index.html and the charter-based bodies such as the Human Rights Commission, http://www.unhchr.ch/html/ menu2/2/chr.htm. "Sixth committee summary treaty actions" is a good Google search (though Google does not support stemming, and "treaty or treaties" may be what one would try). "Sixth Committee treaties" throws the search off into several specific documents of which one has to read summaries and none, on

9 United Nations, Yearbook of the United Nations, 1946/47- ( New York: United Nations, Dept. of Public Information, 1947- ). 
page one at least, constitutes overall treaty actions. But with familiarity, one can assist patrons with this type of internet search as a start.

\section{CASE STUDY: OPTIONAL PROTOCOL TO THE CEDAW}

In writing a research manual on the Optional Protocol to the Convention on the Elimination of all Forms of Discrimination against Women, I had occasion to compare the results of the web alone, as against combined format searching, and discovered that at the Optional Protocol site, little of the true travaux are archived. At the Division for the Advancement of Women Optional Protocol site, http://www.un.org/womenwatch/daw/ cedaw/protocol/undocs.htm, reached also by search engine with "optional protocol draft women," one would start at the $13^{\text {th }}$ session of CEDAW (1994) and work one's way though reports which mention it. But by including a search of the yearbook and UN-I-QUE, one can combine the power of the Internet and the Fourth World Conference on Women website. A/CONF.177 documents are there, though not all pertain directly to the Optional Protocol. There seemed no getting around using the footnotes to documents in order to refine the search.

Search engines such as www.alltheweb.com give more refined results just on "optional protocol women" and take one to the page with the initial definition of the text and the project. Certainly greater relevance scoring in search engines helps until more documents are made freely available and searchable on the web.

AGAINST INTERPRETATION ${ }^{10}:$ TEXTS AND BIAS. WE DRIVE THE WEB FOR INFORMATION; IT DOES NOT DRIVE US.

The final lesson to be learned from treaty travaux research is that once you learn something, it changes. In E/CN.6/1999/L.2, a limited distribution document from the Commission on the Status of Women (CN.6) we find that "open-ended working group" is the name of the principal drafting body for the Optional Protocol to CEDAW. The literal nature of searching will have to give

${ }^{10}$ This is meant in the moderately deconstructionist sense of art and literature critic Susan Sontag's work of the same name. Otherwise I should be accused of undermining the rationale behind treaty travaux in the first place! Experience and text are in a kind of reflexive relationship. See generally Susan Sontag, Against interpretation, and other essays, (New York Farrar, Straus \& Giroux, 1966). 
way to smarter search engines which know when to drop a word or two. Recent news articles describe the computerized autos that are developing ${ }^{11}$ and which will one day drive us to destinations. This is a big boon to people like myself with a poor sense of direction and a nervous approach to highway exit signs. But inevitably, I thought while reading it, the cars will come with popular destinations programmed in, like...Disneyland....and many people will probably go there because there will be no need to map it and watch the signs. What about those other destinations? We will still have to tell the car to go there, even if it knows how. Already bias in information is toward the big treaties and larger web sites. As information professionals, we still need the background knowledge to make sure we can get to all the other places in cyberspace, or in print, that we want to go. We are still a little bit wiser than the web.

${ }^{11}$ See Jerry Morris, "Globe-trotting; need directions? your car can give them," The Boston Globe, July 22, 2001, Travel section, p. K2; and Stephen Drucker, "Hot Wheels That Are Adult Toys," The New York Times, July 22, 2001, Section 5; Page 11; Column 1; Travel Desk. 